\title{
Natural variation for seed physical, biochemical, and culinary traits in common bean (Phaseolus vulgaris $\mathrm{L}_{\text {.) }}$
}

\author{
Iram Saba ${ }^{1}$, Parvaze A. Sofi' ${ }^{1}$, U. K. Kandoliya ${ }^{2 \star}$, Z. A Baba ${ }^{1}$ \\ 'Department of Agriculture, Faculty of Agriculture, Sher-e-Kashmir University of Agricultural Sciences and Technology of Kashmir, \\ Wadura, Sopore, 193201, Jammu \& Kashmir, India, ²Department of Food Technology Laboratory, Junagadh Agricultural University, \\ Junagadh - 360 001, Gujarat, India
}

Received: 14.07 .2015

Revised: 16.11 .2015

Accepted: 17.11.2015

Published: 17.11 .2015

*Address for correspondence:

Parvaze A. Sofi, Department of Plant Breeding \& Genetics, Faculty of Agriculture, SKUAST-K, Wadura, Sopore, 193201, J\&K E-mail: parvazesofi@gmail. com

\begin{abstract}
A total of 20 genotypes of common bean including 17 breeding lines were evaluated for various seed physical, nutritional, and culinary traits viz., seed color, seed shape, seed brilliance, seed coat pattern, seed length, seed breadth, and seed weight, traits protein content, phytic acid, raffinose, water absorption percentage, coat percentage, swelling, and hydration coefficient as well as cooking score. Most of the genotypes were kidney shaped with plain seed coat and medium seed brilliance. Among biochemical traits, the highest protein content was recorded for Arka Anoop (22.15\%) followed by WB-341 (21.45\%), WB-216 (21.16\%), and WB-249 (20.99). Low phytic acid was recorded in WB-970 (0.440\%), WB-258 (0.968\%), and WB-102 (1.068\%). Low values for raffinose was recorded for WB-102 $(3.800 \mathrm{mg} / \mathrm{g})$ followed by WB-482 $(3.833 \mathrm{mg} / \mathrm{g})$. Highest water absorption percentage was recorded for WB-249 (136.363), Arka Anoop (131.818), and SFB-1 (126.923). The swelling coefficient was the highest in the case of WB-642 (300.000), WB-249 (266.667), and WB-335 (250.000), whereas the lowest values for swelling coefficient were recorded in case of WB-341 (114.285), WB-216 (145.454), and WB-1006 (124.554). Among correlations between various seed physical, biochemical and culinary traits, raffinose was positively and significantly correlated with phytic acid. Phytic acid was also significantly and positively correlated with protein, coat proportion, and 100 -seed weight. Coat proportion was negatively correlated water absorption percentage, swelling coefficient, hydration coefficient as well as cooking time score. Cooking time score was positively correlated with hydration and swelling coefficients as well as seed weight but negatively correlated with coat proportion.
\end{abstract}

KEY WORDS: Anti-nutritional factors, common bean, culinary traits, nutritional traits

\section{INTRODUCTION}

Common bean (Phaseolus vulgaris L.) is the most important food legumes of the genus Phaseolus and accounts for about $85 \%$ of all the Phaseolus species grown over the world and is the second most important commercial legume crop after Soybean. It is also known as Dry bean, Green bean, Snap bean, String bean, Wax bean, Field bean, French bean, Pinto bean, Haricot bean, Kidney bean, Black bean, Turtle bean, Navy bean, Great Northern bean, etc. It is the most widely distributed and consumed legume species of the genus Phaseolus (Freyt and Debouck, 2002). There are five cultivated species of the genus Phaseolus namely the common bean (P. vulgaris), the yearlong bean (Phaseolus polyanthus), the runner bean (Phaseolus coccineous), the tepary bean (Phaseolus acutifolius), and the lima bean (Phaseolus lunatus). Among these five domesticated species, the common bean (P. vulgaris) accounts for more than $85 \%$ of the cultivated crop worldwide and is by far the most widely consumed grain legume in the world. It is grown in both subtropical and temperate regions throughout the world under varied farming systems. Even though cereals comprise the bulk of agricultural production, pulses mainly common bean constitute an important component of the diet due to being a nearly complete food and deeply rooted in food habits and culture. Common bean locally called as Rajmash is usually cultivated at higher elevations in hilly states of North and North East. In the northern India, they are largely cultivated in Chamba, Kinnaur, Rajouri, Bhaderwah, Kishtwar, Uri, Kupwara, Shopian, etc. 
Quality is an important aspect of common bean breeding. The value of common bean as a component of the diet is due to its being a cheap source of protein. Like other legumes, it supplies ample quantity of proteins. The largest fraction of bean proteins is made up by storage proteins, which contribute to up to $80 \%$ of the total protein. Storage proteins are represented by phaseolin and legumin (7S and $11 \mathrm{~S}$ globulins, respectively) and the APA proteins comprising $\alpha$-Amylase inhibitor, Phytohemagglutinin, Arcelin, a group of lectin-related polypeptides. All the protein types except the legumins are glycoproteins. Among the different fractions phaseolins are most abundant accounting for about $50 \%$, followed by APA proteins (15\%) and legumins (10\%).

However, common bean also contains certain antinutritional factors such as phytic acid that chelates iron and reduces its bioavailability as well as raffinose that causes flatulence. Phytic acid (myo-inositol-1, 2, 3, 4, 5, 6-hexakisphosphate) is considered to be the most abundant storage form of phosphorus present in food grains. Phytic acid is accumulated in the bean seeds within single-membrane storage organelles called as protein bodies. These are mostly complexed with minerals ( $\mathrm{K}, \mathrm{Mg}, \mathrm{Ca}, \mathrm{Fe}$ and $\mathrm{Zn}$ ) and are known as phytins (Raboy, 1997). Phytic acid represents from $65 \%$ to $85 \%$ of the total seed P (Reddy et al., 1989). As a polyanion, phytate is an effective chelator of positively charged molecules and has the potential to form stable insoluble complexes with minerals and proteins. These complexes confer to phytate its notorious anti-nutritional properties, which are particularly important for the humans and non-ruminants, such as poultry, swine, and fish that lack the hydrolytic enzyme phytase in their digestive tract and excrete a large fraction of these phytin salts (Cheryan, 1980). Moreover, the amount of phytate that breaks down during the storage of common beans appears to be the most important trait in the development of the hard to cook phenomenon (Coelho et al., 2007).

Many higher plants accumulate raffinose during seed maturation. These carbohydrates consist of Gal units linked to Sucrose via $\alpha-(1 \rightarrow 6)$ glycosidic linkages. raffinose family oligosaccharides (RFOs) have been proposed to act as protective agents during desiccation and storage of seeds in the dry state (Obendorf, 1997), although there is no evidence for a causal relationship between their accumulation and the acquisition of desiccation tolerance (Bentsink et al., 2000; Buitink et al., 2000). Although RFOs have long been regarded as anti-nutritional factors in human nutrition, recent data support a beneficial role of RFOs as so-called prebiotics, by specifically stimulating the growth of remedial gut bacteria. Along with indigestible starch, RFOs (raffinose, stachyose, and verbascose) may lead to digestive upset. The human digestive system lacks $\alpha$-galactosidase that breaks the $\alpha, 1,6$-linkages in raffinose oligosaccharides. As a result, these oligosaccharides pass on to lower intestines where enteric bacteria degrade them to hydrogen, methane, and carbon dioxide which are expelled as flatus. However, breeding for lower raffinose is a tricky situation for plant breeders as it provides membrane stability to seeds in cold wet soils during germination when seeds are rehydrating especially in white seeded beans.

Cooking time is important in view of the energy requirements associated with cooking and energy being a major issue in developing nations where beans are largely consumed. Reducing carbon footprints through reduced cooking time is a strong ecological rationale for using this trait while developing varieties. In fact, the most energydemanding process in the whole market chain is probably cooking. Even in countries like the USA, where agriculture is almost entirely mechanized, and production consumes large amounts of energy, $48 \%$ of energy in the food chain is spent in industrial processing and home cooking. Cooking common bean has a particularly high energy requirement because of its relatively long cooking time. Therefore, breeding for short cooking time emerges as a consumerpreferred trait in the developing world. The procedure of evaluation of common bean genotypes for cooking time by CIAT in Cali, Colombia, is based on a cooking time index derived from a bardrop cooker (Jackson and Varriano-Marston, 1981). Although a useful and reliable technique, it is laborious and time-consuming for a large number of samples. It has been suggested that the amount of water dry beans absorb during soaking before cooking may be a reliable indicative of the amount of time required to render them soft and palatable to eat. Hence, the water absorption of a genotype may be a useful and rapid indirect selection method to screen germplasm for cooking time. A large number of studies have been undertaken to assess the variation among the genotypes for various seed traits including water absorption for screening material for seed culinary properties (Krista and Hosfield, 1991; Santalla et al., 1999 and Vakali et al., 2009, Sofi et al., 2014).

\section{MATERIALS AND METHODS}

The present study was carried out during 2014-2015 at Regional Research Station Wadura. 20 genotypes of common bean including 17 breeding lines representing diverse market classes and three released varieties were evaluated for various seed physical properties viz., seed 
color, seed shape, seed brilliance, seed coat pattern, seed length, seed breadth, and seed weight. Among nutritional traits, protein content was estimated and among antinutritional factors phytic acid and raffinose were estimated. Among seed culinary traits, water absorption percentage, coat percentage, swelling, and hydration coefficient as well as cooking score were estimated. The three varieties used in the present study were Shalimar Rajmash-1, Shalimar French Bean-1, and Arka Anoop. Shalimar Rajmash-1 is a pulse type variety, whereas Shalimar French Bean- 1 is a vegetable type variety released by SKUAST-K. Arka Anoop is a variety released by IIHR, Bangalore. The methodologies used are detailed as below.

\section{Seed Physical Parameters}

Seed length and breadth was measured using vernier calliper and averaged across five representative seeds for each genotype. 100-seed weight was calculated on a randomly drawn sample of 100 sun-dried seeds and averaged across three samples.

\section{Protein Content}

Protein content was estimated using Near Infrared Reflectance Spectroscopy (CROP SCAN 2000G) facility at Seed Technology Laboratory of SKUAST-K. It is a quick and non-destructive method for estimation of protein content.

\section{Phytic Acid}

Phytic acid content was estimated according to modified Haug and Lantzsch (1983) method. The determination was based on the indirect spectrophotometric determination of phytic phosphorus in dry bean extracts. Phytic acid was precipitated by addition of ferric ammonium sulfate. Part of iron forms insoluble ferric phytate, and the remaining iron was determined spectrophotometrically. Calibration curve was prepared by series of standard solutions of the sodium salt of the phytic acid. All reagents were of analytical grade procured from HIMEDIA. $0.5 \mathrm{~g}$ of powdered sample was extracted with $100 \mathrm{ml}$ of $2.4 \% \mathrm{HCl}$ during $3 \mathrm{~h}$ with constant stirring. The extract was filtered through Whatman No 41 filter paper. $0.5 \mathrm{ml}$ of extract was transferred into a glass tube with stopper, ammonium iron (III) - sulfate solution $\left(0.2 \mathrm{~g}\right.$ of $\mathrm{NH}_{4} \mathrm{Fe}\left(\mathrm{SO}_{4}\right)_{2} \cdot 12 \mathrm{H}_{2} \mathrm{O}$ dissolved in $100 \mathrm{ml}$ of $2 \mathrm{~mol} / \mathrm{L} \mathrm{HCl}$ and filled to mark with distilled water) was added. The closed glass tube was held in boiling water bath for $30 \mathrm{~min}$, cooled in refrigerator for $15 \mathrm{~min}$ and left to attain room temperature. Tube was centrifuged at $3000 \mathrm{r} / \mathrm{min}$. About $1 \mathrm{ml}$ of supernatant was transferred to another glass tube and $1.5 \mathrm{ml}$ of 2,2'-bipyridine solution (10 g 2,2'-bipyridine dissolved in $10 \mathrm{ml}$ thioglycolic acid and filled to mark with distilled water) was added. After exactly defined time, absorbance was measured at $519 \mathrm{~nm}$.

\section{Cooking Time}

The procedure of cooking in an autoclave followed the method described by Revilla and Vivar-Quintana (2008), with modifications. A total of 50 soaked grains were placed in a glass beaker, filled with $200 \mathrm{~mL}$ of distilled water, covered with watch glass, and cooked under the conditions $110^{\circ} \mathrm{C}$ for $5 \mathrm{~min}$. The following scale was used for scoring cooking properties of bean genotypes.

\begin{tabular}{lll}
\hline Scale & Designation & Description \\
\hline 1 & Undercooked & $\begin{array}{l}\text { Grain is difficult or not able to } \\
\text { smash and cotyledon feels hard } \\
\text { Grain is less difficult to smash and } \\
\text { cotyledon feels slightly hard }\end{array}$ \\
3 & Slightly undercooked & $\begin{array}{l}\text { Grain is firm but smashes easily } \\
\text { and cotyledon feels soft }\end{array}$ \\
4 & Slightly overcooked & $\begin{array}{l}\text { There is little resistance to smash } \\
\text { grain and cotyledon feels mushy } \\
\text { Grain is easily pressed into a mush }\end{array}$ \\
\hline
\end{tabular}

\section{Raffinose}

Raffinose was estimated using the Megazyme Kit (Megazyme Inc., Ireland). The basic principle of the estimation of raffinose is based on enzymatic reactions using $\alpha$-galactosidase and invertase. The raffinose was estimated spectrophotometrically at $510 \mathrm{~nm}$.

\section{Water Absorption Percentage}

Seed water absorption parameters were calculated as per the procedure of Bishnoi and Khetarpaul, 1993. The moisture contents of the dry bean samples were equilibrated to each other before analysis of water absorption by storing them for 2 weeks in sealed plastic containers at ambient temperatures and relative humidity. The percent water absorption was determined by the first soaking 30 seeds for $24 \mathrm{~h}$ in deionized water at room temperature and dividing the difference in weight before and after soaking by the dry weight of the 30 -seed sample. Seed coat proportion was determined on 20 seeds per plot, as the ratio in weight between coat and cotyledon expressed in percentage, after removing the seed coat from the cotyledons, both after soaking and keeping them for $24 \mathrm{~h}$ at $105^{\circ} \mathrm{C}$.

\section{Swelling and Hydration Coefficients}

Swelling and hydration coefficients were determined using the Youssuf's method (1978). The raw bean seeds were soaked in distilled water for $24 \mathrm{~h}$, and the volume 
of the bean seeds was estimated before and after soaking by determination of displaced water. The hydration coefficient was calculated as the percentage increase in weight of beans. The swelling coefficient was calculated as the percentage increase in volume of beans after soaking:

Swelling coefficient $(\%)=(\mathrm{Va} / \mathrm{Vb}) \times 100$

Hydration coefficient $(\%)=(M a / M b) \times 100$

Where $M b$, weight of seeds before soaking (g); Ma, weight of bean seeds after soaking $(\mathrm{g}) ; \mathrm{Vb}$, volume of bean seeds before soaking $(\mathrm{mL})$; va, volume of bean seeds after soaking $(\mathrm{mL})$.

\section{RESULTS AND DISCUSSION}

The physical properties of seed are given in Table 1 . The 20 genotypes belonged to diverse market classes with seven seed colors recorded (brown, red, white, chocolate, pink, purple, and yellow). Most of the genotypes were kidney shaped with plain seed coat and medium seed brilliance. The results pertaining to mean performance of seed length, breadth, and 100-seed weight also show a wide range of values among genotypes. The highest seed length was recorded for WB-216 $(1.766 \mathrm{~cm})$ and the lowest recorded for WB-335 (0.966). The highest value for seed breadth was recorded for WB-185 $(0.833 \mathrm{~cm})$ followed by WB-970 (0.828) while as the lowest seed breadth $(0.633 \mathrm{~cm})$ was recorded for WB-642, WB-435, Arka Anoop and Shalimar French Bean-1. Substantial variability for seed length, breadth as well as 100-seed weight has been reported in common bean in local and exotic genotypes of J\&K by Sofi et al., (2014), Sultan et al., (2014), and Wani et al., (2015).
Among biochemical traits (Table 2), highest protein content was recorded for Arka Anoop (22.15\%) followed by WB-341 (21.45\%), WB-216 (21.16\%), and WB249 (20.99\%), whereas lowest value was recorded for recorded for SFB-1 (17.85\%) and WB-921 (17.89\%). There is a great variation reported in protein content in common bean. Silva et al. (2002) evaluated 100 lines of common bean and found substantial variability in protein content ranging from 19.60 to $30.40 \%$. Aliu et al . (2013) estimated protein content in bean populations of Kosovo and recorded an average value of $2.2 \%$ with the highest value of $23.84 \%$. Similarly Mahajan et al., (2015) evaluated 51 local genotypes of common bean in $\mathrm{J}$ and $\mathrm{K}$ and observed protein content in the range of $7-31 \%$. The common bean has high nutritional value, with significant concentrations of protein. It represents the main source of protein for low-income populations especially in developing countries. The identification of lines with high levels of protein and minerals, adds value to the cultivars, without increasing the cost to consumers (Silva et al., 2002).

Substantial variation was recorded for raffinose and phytic acid content also (Tables 2 and 3). Some of the lines had low phytic acid content notably WB-970 (0.440\%), WB258 (0.968\%) andWB-102 (1.068\%), whereas high phytic acid was recorded for Shalimar Rajmash-1 (4.162\%) and WB-216 (3.988\%). There are reports of a very wide range of phytic acid in common beans. Vasić et al., (2012) evaluated 24 common bean genotypes and recorded phytic acid in the range of 0.68-1.07\%, while as Dhole and Reddy (2015) reported the phytic acid content of $0.58-2.00 \%$. Low values for raffinose was recorded for WB-102 (3.800 mg/g) followed by WB-

Table 1: Seed physical parameters of 20 common bean genotypes

\begin{tabular}{|c|c|c|c|c|c|c|c|}
\hline Genotype & Seed color & Seed brilliance & Seed coat pattern & Seed shape & Seed length & Seed breadth & Seed weight \\
\hline WB-83 & Purple & Brilliant & Plain & Cuboidal & 1.333 & 0.800 & 31.106 \\
\hline WB-102 & Chocolate & Brilliant & Plain & Oval & 1.400 & 0.800 & 43.940 \\
\hline WB-185 & Red & Brilliant & Plain & Kidney & 1.500 & 0.830 & 43.863 \\
\hline WB-195 & Chocolate & Medium & Plain & Kidney & 1.533 & 0.733 & 41.106 \\
\hline WB-216 & Pink & Medium & Plain & Kidney & 1.766 & 0.766 & 48.950 \\
\hline WB-249 & White & Medium & Plain & Kidney & 1.166 & 0.566 & 20.592 \\
\hline WB-258 & Red & Medium & Plain & Cuboidal & 1.400 & 0.766 & 34.019 \\
\hline WB-330 & Yellow & Brilliant & Plain & Kidney & 1.466 & 0.766 & 43.205 \\
\hline WB-335 & White & Medium & Plain & Oval & 0.966 & 0.733 & 46.776 \\
\hline WB-341 & Red & Brilliant & Plain & Cuboidal & 1.266 & 0.766 & 38.271 \\
\hline WB-435 & Brown & Medium & Mottled & Cuboidal & 1.000 & 0.633 & 26.932 \\
\hline WB-482 & Brown & Medium & Mottled & Kidney & 1.436 & 0.705 & 39.689 \\
\hline WB-634 & Chocolate & Medium & Plain & Kidney & 1.533 & 0.700 & 32.601 \\
\hline WB-642 & Brown & Dull & Plain & Kidney & 1.466 & 0.633 & 28.349 \\
\hline WB-921 & Brown & Medium & Mottled & Kidney & 1.367 & 0.733 & 42.524 \\
\hline WB-970 & Brown & Brilliant & Plain & Kidney & 1.587 & 0.828 & 41.106 \\
\hline WB-1006 & Red & Medium & Plain & Cuboidal & 1.233 & 0.707 & 30.098 \\
\hline Shalimar French Bean-1 & Brown & Medium & Plain & Kidney & 1.566 & 0.633 & 28.854 \\
\hline Arka-Anup & White & Medium & Plain & Kidney & 1.433 & 0.633 & 31.184 \\
\hline Shalimar Rajmash-1 & Red & Brilliant & Plain & Kidney & 1.633 & 0.733 & 42.524 \\
\hline
\end{tabular}


Table 2: Mean performance of twenty common bean genotypes for seed quality and culinary traits

\begin{tabular}{|c|c|c|c|c|c|c|c|c|}
\hline Genotype & $\begin{array}{c}\text { Raffinose } \\
\mathrm{Mg} / \mathrm{g}\end{array}$ & $\begin{array}{l}\text { Phytic } \\
\text { acid (\%) }\end{array}$ & $\begin{array}{l}\text { Protein } \\
\text { content }\end{array}$ & $\begin{array}{c}\text { Water absorption } \\
\text { percent }\end{array}$ & $\begin{array}{c}\text { Coat } \\
\text { proportion }\end{array}$ & $\begin{array}{l}\text { Swelling } \\
\text { coefficient }\end{array}$ & $\begin{array}{l}\text { Hydration } \\
\text { coefficient }\end{array}$ & $\begin{array}{l}\text { Cooking } \\
\text { time score }\end{array}$ \\
\hline WB-83 & 6.183 & 2.554 & 19.43 & 55.779 & 18.450 & 184.234 & 155.779 & 3 \\
\hline WB-102 & 3.800 & 1.068 & 17.97 & 80.645 & 15.909 & 214.285 & 180.645 & 4 \\
\hline WB-185 & 4.172 & 2.323 & 19.03 & 121.052 & 15.254 & 220.000 & 221.052 & 3 \\
\hline WB-195 & 6.741 & 2.738 & 19.41 & 127.587 & 19.149 & 200.000 & 227.587 & 4 \\
\hline WB-216 & 6.068 & 3.988 & 21.16 & 120.930 & 19.048 & 145.454 & 220.930 & 5 \\
\hline WB-249 & 5.588 & 2.076 & 20.99 & 136.363 & 23.125 & 266.667 & 236.363 & 4 \\
\hline WB-258 & 4.234 & 0.968 & 19.12 & 62.500 & 14.286 & 191.667 & 162.500 & 2 \\
\hline WB-330 & 4.108 & 1.486 & 19.08 & 112.121 & 12.727 & 242.857 & 212.121 & 5 \\
\hline WB-335 & 5.358 & 2.928 & 20.41 & 115.161 & 22.642 & 250.00 & 215.151 & 4 \\
\hline WB-341 & 6.421 & 1.743 & 21.45 & 44.444 & 20.000 & 114.285 & 144.444 & 3 \\
\hline WB-435 & 4.397 & 2.447 & 18.56 & 100.000 & 16.667 & 275.00 & 200.000 & 3 \\
\hline WB-482 & 3.833 & 1.743 & 19.09 & 110.714 & 20.000 & 185.714 & 210.714 & 3 \\
\hline WB-634 & 4.877 & 1.202 & 19.84 & 126.087 & 17.143 & 216.667 & 226.087 & 3 \\
\hline WB-642 & 6.951 & 2.341 & 20.30 & 115.000 & 18.182 & 300.000 & 215.000 & 3 \\
\hline WB-921 & 5.055 & 1.576 & 17.89 & 110.000 & 11.111 & 177.778 & 210.000 & 4 \\
\hline WB-970 & 5.112 & 0.440 & 18.36 & 120.689 & 14.286 & 212.500 & 220.689 & 3 \\
\hline WB-1006 & 4.004 & 2.097 & 18.38 & 76.967 & 21.766 & 124.554 & 176.967 & 2 \\
\hline Shalimar French Bean-1 & 5.067 & 1.976 & 17.85 & 126.923 & 14.286 & 200.000 & 226.923 & 3 \\
\hline Arka-Anup & 5.358 & 1.577 & 22.15 & 131.818 & 5.000 & 240.000 & 231.818 & 4 \\
\hline Shalimar Rajmash-1 & 5.078 & 4.162 & 19.97 & 116.667 & 19.298 & 225.000 & 216.667 & 3 \\
\hline LSD & 1.630 & 0.472 & 0.844 & 39.146 & 10.073 & 123.313 & 39.146 & 0.367 \\
\hline
\end{tabular}

Table 3: Descriptive statistics of eleven seed physical, biochemical, and quality traits

\begin{tabular}{lccc}
\hline Trait & Mean & Range & $\begin{array}{c}\text { Standard } \\
\text { error }\end{array}$ \\
\hline Raffinose (mg/g) & $5.120 \pm 0.999$ & $3.800-6.951$ & 0.217 \\
Phytic acid (\%) & $2.076 \pm 0.810$ & $0.440-4.162$ & 0.207 \\
Protein content & $19.522 \pm 1.273$ & $17.850-22.150$ & 0.278 \\
Water absorption percent & $105.572 \pm 27.393$ & $44.444-136.363$ & 5.990 \\
Coat proportion & $16.916 \pm 4.377$ & $5.000-23.125$ & 0.961 \\
Swelling coefficient & $209.331 \pm 48.705$ & $114.285-300.000$ & 10.632 \\
Hydration coefficient & $205.571 \pm 27.393$ & $144.444-236.363$ & 5.990 \\
Cooking time score & $3.400 \pm 0.837$ & $2.000-5.000$ & 0.183 \\
l00-Seed weight & $36.784 \pm 9.225$ & $20.592-48.950$ & 2.026 \\
Seed length & $1.402 \pm 0.198$ & $0.966-1.766$ & 0.045 \\
Seed breadth & $0.723 \pm 0.074$ & $0.566-0.830$ & 0.016 \\
\hline
\end{tabular}

$482(3.833 \mathrm{mg} / \mathrm{g})$ whereas highest value was found for WB-642 (6.951 mg/g) followed byWB-195 (6.741 mg/g) and WB-341 $(6.421 \mathrm{mg} / \mathrm{g})$. The released varieties had significantly higher raffinose content as compared to the breeding lines. Raffinose is an anti-nutritional factor in that it causes flatulence, but it is reported to provide cell membrane stability during seed maturation and desiccation thereby preventing cracking (Lugol and Leopold, 1995). In the present study, higher raffinose content was recorded in case of white and light seeded lines which is a desirable feature as such genotypes are susceptible to membrane damage during seed germination and maturation . Considerable variability existed among common bean genotypes in raffinose content between 1.63 and $7.04 \mathrm{mg} / \mathrm{g}$ (Hernández et al., 2002). Variability for raffinose content has also been reported in beans by McPhee and Meyers (1996), Casanas et al., (1999) and McPhee et al., (2002).
Among water absorption traits that define the culinary properties of beans, water absorption percentage, coat proportion, swelling and hydration coefficients as well as cooking time score were recorded. 15 out of the 20 genotypes absorbed more water than their weight. Highest water absorption percentage was recorded for WB-249 (136.363), Arka Anoop (131.818) and SFB-1 (126.923), whereas few breeding lines absorbed water less than their weight and the lowest value was recorded for WB-341 (44.444), WB-83 (55.779), WB-258 (62.5000) and WB-1006 (76.967). The water absorption percentage was invariably low in case of small red types. The seed coats in small red types are tightly attached with the cotyledons that might limit water imbibition upon soaking. Similar trend was observed for hydration coefficient. The coat percentage was lowest in the case of Arka Anoop (5.000\%) followed by WB-921 (11.111\%) and WB-330 (12.727\%) whereas highest proportion of coat was recorded for WB$249(23.125 \%)$ followed by WB-335 (22.642\%) and WB-1006 (21.776\%). The swelling coefficient that determines the increase in volume on soaking was highest in the case ofWB-642 (300.000),WB-249 (266.667) and WB-335 (250.000), whereas lowest values for swelling coefficient were recorded in case of WB-341 (114.285), WB-216 (145.454) and WB-1006 (124.554). Hydration and swelling coefficients that reflect the capacity of seeds to imbibe water in a reasonable length of soaking time. Rapid uptake of water is a desirable attribute of legume grain used for food. The swelling coefficient behaved in the same way as hydration coefficient because swelling depends mainly on the amount of water absorbed. Shimelis 
Table 4: Correlation between various seed physical, quality and culinary traits

\begin{tabular}{|c|c|c|c|c|c|c|c|c|c|}
\hline Trait & $\begin{array}{c}\text { Raffinose } \\
(\mathrm{mg} / \mathrm{g})\end{array}$ & $\begin{array}{l}\text { Phytic } \\
\text { acid (\%) }\end{array}$ & $\begin{array}{l}\text { Protein } \\
\text { content }\end{array}$ & $\begin{array}{l}\text { Water absorption } \\
\text { percent }\end{array}$ & $\begin{array}{c}\text { Coat } \\
\text { proportion }\end{array}$ & $\begin{array}{l}\text { Swelling } \\
\text { coefficient }\end{array}$ & $\begin{array}{l}\text { Hydration } \\
\text { coefficient }\end{array}$ & $\begin{array}{l}\text { Cooking } \\
\text { time score }\end{array}$ & $\begin{array}{c}\text { Seed } \\
\text { weight }(g)\end{array}$ \\
\hline Raffinose (mg/g) & - & $0.379 *$ & $0.551 * *$ & 0.060 & 0.197 & 0.030 & 0.060 & 0.201 & 0.028 \\
\hline Phytic acid (\%) & - & - & $0.340 *$ & 0.174 & $0.444 * *$ & 0.004 & 0.174 & 0.226 & $0.344^{*}$ \\
\hline Protein content & - & - & - & 0.113 & 0.095 & 0.073 & 0.113 & 0.290 & 0.030 \\
\hline Water absorption percent & - & - & - & - & -0.166 & $0.524 * *$ & $0.999 * *$ & $0.439 *$ & 0.061 \\
\hline Coat proportion & - & - & - & - & - & -0.136 & -0.166 & -0.162 & -0.001 \\
\hline Swelling coefficient & - & - & - & - & - & - & $0.524 * *$ & 0.181 & $-0.448 * *$ \\
\hline Hydration coefficient & - & - & - & - & - & - & - & $0.439 *$ & 0.061 \\
\hline Cooking time score & - & - & - & - & - & - & - & - & $0.504 * *$ \\
\hline Seed weight & - & - & - & - & - & - & - & - & - \\
\hline
\end{tabular}

and Rakshit (2005) determined the hydration and swelling coefficients for 8 different bean varieties, cultivated in Ethiopia. They noticed that the hydration and swelling coefficients varied widely across the bean varieties. It was reported that the legumes having the higher hydration and swelling coefficients require less cooking time. Hardness after cooking increases with a decrease of hydration capacity $(\mathrm{g} / \mathrm{seed})$ in the different varieties, but decreases with cooking time. Hence, the consumers and processors alike prefer varieties with low cooking time and low hardness value (Bishnoi and Khetarpaul, 1993; Wang et al., 2003; Sofi et al., 2014). Desirable cooking time score was recorded for WB-216 and WB-330 (5) followed by WB102,WB-195, WB-249.WB-335, WB-921 AND Shalimar French Bean-1 (4) while as other lines were medium to hard in cooking.

Among correlations between various seed physical, biochemical and culinary traits, raffinose was positively and significantly correlated with phytic acid. This is possibly due to the fact that the biosynthetic pathways of synthesis of both raffinose and phytic acid share a common intermediate myoinositol-1-phosphate. In fact, the mutations in the MIPS enzyme have been reported to decrease the both in soybean (Hitz et al., 2011). Similar results have been reported by Zhawar et al., (2011) in chickpea. Phytic acid was also significantly and positively correlated with protein. The positive correlation of phytic caid and protein content has been also reported in beans (Coelho et al., 2007a), chickpea and pigeonpea (Chitra et al., 1995), Soybean (Raboy et al., 1984) and in wheat (Raboy et al., 1990) and in rice (Wei et al., 2007). Increasing level of PA decreases protein availability by forming phytate-protein bounds as well (Reddy et al., 1982). Henrik et al. (2002) revealed that PA was stored in protein-crystalloid in grains of cereal and legumes and speculated that the synthesizing metabolism of grain PA probably was closely related to the accumulation of protein in rice grains. However, no significant correlation between the content of PA and the accumulation of total protein was found in a study on the legume seeds (Morre et al., 1990) and study on rice varieties (Wu et al., 2007). Although PA can inhibit iron absorption due to their ability to form non-absorbable complexes with iron in the gastrointestinal tract, they also fulfill essential biological functions in the plant. PA, stored in seeds, provides the growing seedling with phosphorous and essential minerals at the whole- plant level and also appears to be involved in signaling and response to plant pathogens. (Bohn et al., 2008; Murphy et al., 2008). Therefore, plant breeders have to maintain a certain level of phytic acid while breeding for reduced anti-nutritional factors in beans. Phytic acid was also positively correlated with coat proportion and 100seed weight. Coat proportion was negatively correlated water absorption percentage, swelling coefficient, hydration coefficient as well as cooking time score. Cooking time score was positively correlated with hydration and swelling coefficients as well as seed weight but negatively correlated with coat proportion. Mavromatis et al., (2012) also made a comparative study in common bean for seed physicochemical traits and concluded that seed physicochemical traits including the traits used in present study could be effectively used for comparing large set of germplasm lines for cooking qualities as the varieties that have high hydration and swelling capacities are usually fast to cook (Jackson and Varriano-Marston, 1981, Castillo et al., 2008). However, the lines that have lower hydration and swelling capacities usually have longer storage life. Similar results in correlation among seed physical and culinary traits have been reported by Sofi et al., (2014).

\section{ACKNOWLEDGMENTS}

The first author gratefully acknowledges the financial support from DST New Delhi. Iram Saba is supported by CSIR fellowship.

\section{REFERENCES}

Aliu S, Rusinovci I, Fetahu S, Bislimi K, Thaqi M, Reçica X. Chemical compostion of common bean (Phaseolus vulgaris L.) grown in Kosovo. Povrćarstvo, ukrasno, 
aromaticȟo i ljekovito bilje 2013;49:275-9.

Bentsink L, Alonso-Blanco C, Vreugdenhil D, Tesnier K, Groot SPC, Koornneef M. Genetic analysis of seedsoluble oligosaccharides in relation to seed storability of Arabidopsis. Plant Physiol 2000;124:1595-1604.

Bishnoi S, Khetarpaul N. Variability in physicochemical properties and nutrient components of different pea cultivars. Food Chem 1993;47:371-3.

Bohn L, Meyer AS, Rasmussen SK. Phytate: Impact on environment and human nutrition. A challenge for molecular breeding. J Zhejiang Univ Sci B 2008;9:165-91.

Buitink J, Hemminga MA and Hoekstra FA. Is there a role for oligosaccharides in seed longevity? An assessment of intracellular glass stability. Plant Physiol 2000;122:12171224.

Casanas F, Pijole M, Castillo R, Almirali A, Sanchez E, Nuez F. Variability in texture characters and chemical components of common bean. J. Food Sci. Agri. 2006;86:2445-2449.

Castillo RR, Almiral A, Valero J, Casanas F. Protected designation of origin in beans (Phaseolus vulgaris L.): Towards an objective approach based on sensory and agromorphological properties. J Sci Food Agric 2008;88:1954-62.

Chitra U, Vimala V, Singh U, Geervani P. Variability in phytic acid content and protein digestibility of grain legumes. Plant Foods Hum Nutr 1995;47:163-72.

Cheryan M. Phytic acid interations in food systems. Crit Rev Food Sci Nutr 1980;13:297-335.

Coelho CM, Bellato CM, Santos JC, Ortega EM, Tsai SM. Effect of phytate and storage conditions on the development of the hard to cook phenomenon in common beans. J Sci Food Agric 2007a;87:1237-43.

Dhole V, Reddy K. Genetic variability for phytic acid content in mung bean. Crop J. 2015;89:212-215.

Haug W, Lantzsch HJ. Sensitive method for rapid determination of phytate in cereals and cereal products. J Sci Food Agric 1983;34:1423-6.

Hernández CJ, Blanças-Carrazco ME, Sánchez-Domínguez S, Rodríguez-Pérez E, García RG, Bemal-Lugo I. Effect of soaking on oligosaccharide content in common beans. BIC Rep 2002;44:159-60.

Henrik BP, Lisbeth DS, Preben BH. Engineering Crop Plant: Getting a handle on phosphate, Trends Plant Sci. 2002;7:118-124.

HitzW, Carlson T, Kerr P, Sebstain S. Biochemical and molecular characterisation of a mutant that confers decreased raffinose and phytic acid in soybean. Plant Physiol 2011;128:650-60.

Jackson GM, Varriano-Marston E. Hard-to-cook phenomenon in beans: Effects of accelerated storage on water absorption and cooking time. J Food Sci 1981;46:799-803.

Krista CS, Hosfield GL. Genotype environmental effects on food quality of common bean: Resource-efficient testing procedures. J Am Soc Hortic 1991;116:732-6.

Lugol I, Leopold AS. Seed stability during storage: Raffinose content and seed glassy state. Seed Sci. Res. 1995;5:75-80.

Mahajan R, Zargar SM, Aezum AM, Farhat S, Gani M, Agrawal GK, et al. Evaluation of iron, zinc, and protein contents of common bean (Phaseolus vulgaris L.). Genotypes: A collection from Jammu \& Kashmir, India. Legume Genom Genet 2015;6:1-7. DOI: 10.5376/ lgg.2015.06.0002.

Mavromatis AG, Arvanitoyannis IS, ChatzitheodorouV, Kaltsa A, Patsiaoura I, Nakas CT. A comparative study among landraces of Phaseolus vulgaris $\mathrm{L}$. and P. coccineus L. based on molecular, physicochemical and sensory analysis for authenticity purposes. Sci Hortic 2012;144:10-8.

McPhee K, Meyers J. Screening common bean germplas for rafinose group oligosaccharides. BIC Rep 1996;38:255-7.

McPhee K, Zemerta R, Brown J, Meyers J. Genetic analysis raffinose group oligosaccharides in common bean. J Am Soc Hortic 2002;127:376-82.

Morre DJ, Boss W, Loewus FA. 1990. Inositol Metabolism in Plants. New York: Willey-Liss Press, pp. 52-73.

Murphy AM, Otto B, Brearley CA, Carr JP, Hanke DE. A role for inositol hexakisphosphate in the maintenance of basal resistance to plant pathogens. Plant J 2008;56:638-52.

Obendorf RL. Oligosaccharides and galactosyl cyclitols in seed desiccation tolerance. Seed Sci Res 1997;7:63-74.

Raboy V, Noaman MM, Taylor GA, Pickett SG. Grain phytic acid and protein are highly correlated in winter wheat. Crop Sci 1990;31:631-5.

Raboy V. Accumulation and storage of phosphate and minerals. In: Cellular and molecular biology of plant seed development. (Eds.): B.A. Larkins and I.K. Vasil. Kluwer academic publishers Dordrecht, The Neitherlands: 1997;441-77.

Raboy V, Dickinson DB. Effect of phosphorus and zinc nutrition on soybean seed phytic acid and zinc. Plant Physiol., 1984;75:1094-1098.

Reddy NR, Pierson MD, Sathe SK, Salunkhe DK. Phytates in Cereals and Legumes. Boca Raton: CRC Press; 1989. p. 152 .

Reddy NR, Sathe SK, Salunkhe DK. Phytates in legumes and cereals. Adv. Food Res., 1982;28:35-39.

Revilla AM, Vivar-Quintana A. Effect of canning process on texture of Faba beans (Vicia faba). Food Chem 2008;106:310-4.

Santalla M, Fueyo M, Rodino A, Montero I, de Ron A. Breeding for culinary and nutritional quality of common bean (Phaseolus vulgaris L.). in intercropping systems with maize (Zea mays L.). Biotechnol Agron Soc Environ 1999;3:225-9.

Shimelis EA, Rakshit SK. Proximate composition and physicochemical properties of improved dry bean (Phaseolus 
vulgaris L.). Varieties grown in Ethiopia. Swiss Soc Food Sci Technol 2005;38:331-8.

Silva CA, Abreu A, Ramalho M, Correa A, Silva L. Genetic variability for protein and minerals content in common bean lines. BIC Rep 2002;44:144-5.

Sofi PA, Wani SA, Zargar MY, Sheikh FA, ShafiT. Comparative evaluation of common bean (Phaseolus vulgaris L.). germplasm for seed culinary traits. J Appl Hortic 2014;16:54-8.

Sultan SM, Dar SA, Dand SA, Natarajan S. Diversity of common bean in Jammu and Kashmir, India: A DIVA- geographic information system and cluster analysis. J Appl Nat Sci 2014;6:226-33.

Vakali C, Papathanasiou F, Papadopoulos I, Tamoutsidis E. Prelimenary results on a comparative study evaluating landraces of common bean (Phaseolus vulgaris L.). Under organic agriculture in a protected area in Greece. Proceedings of $2^{\text {nd }}$ Scientific Conference within the Framework of the $9^{\text {th }}$ European Summer Academy on Organic Farming, Lednice na Morave ${ }^{\vee}$, Czech Republic.

Vasić MA, Tepić AN, Mihailović VM, Mikić AM, GvozdanovićVarga JM, Šmić ZM, et al. Phytic acid content in different dry bean and faba bean landraces and cultivars. Rom Agric
Res 2012;29:79-85.

Wani IA, Sogi D, Wani AA. Gill BS. Physical and cooking characteristics of some Indian kidney bean (Phaseolus vulgaris L.) cultivars. J Saudi Soc Agric Sci. Available from: http: / /www.dx.doi.org/10.1016/j.jssas.2014.12.002. [Last Accessed 15 July, 2015].

Wang T, Domoney C, Hedley C, Casey R, Grusak M. Can we improve nutritional quality of legumes. Planyt Physiology. 2003;131:886-891.

Wei WU, Cheng F, Liu Z, Wei K. Difference of phytic acid content and its relation to four protein composition contents in grains of twenty-nine japonica rice varieties from Jiangsu and Zhejiang provinces, China. Rice Sci 2007;14:311-4.

Wu X, James R, Anderson A. Mineral contents in seed coat and canning quality of selected cultivars of dark red kidney beans (Phaseolus vulgaris L.). J Food Process 2005;29:63-74.

Youssuf MM. A study of factors affecting the cook ability of faba beans (Vicia faba L.), Ph.D. Thesis, College of Agricultural University of Alexandria, Egypt. 1978.

Zhawar V, Kaur N, Gupta A. Phytic acid and raffinose oligosaccharide metabolism in chickpea seeds. Physiol Mol Biol Plants 2011;17:355-6. 